\title{
Exploring Local Conceptions of Poverty, Wealth and Well-Being: Field Evidence from Mashonaland West Province of Zimbabwe
}

\author{
Oliver Mtapuri*
}

\begin{abstract}
This article presents the conceptions of poverty by the poor in Mashonaland West Province of Zimbabwe. It seeks to broaden the discussion of poverty around the definition of the poor from the perspective of the poor. A cause-effect framework for poverty analysis is proposed, as well as the introduction of the notion of 'enclavity' within a family in poverty discourse. These are the two primary contributions of this paper. The research suggests that, due to deepening poverty, people create enclaves around husband/wife relationships as a new form of resilience/collectivity. While the poor suffer from a lack of assets, ethics and networks breakdown as a result of poverty. The results suggest, as elsewhere, that poverty is multifaceted, thus driving to some confluence of conception.
\end{abstract}

\section{Résumé}

L'article présente les conceptions que les populations démunies de la Province Ouest de Mashonaland ont de la pauvreté. Il cherche à élargir les points de vue sur la pauvreté en s’appuyant sur la définition qu'en donne les personnes démunies, à partir de leurs propres perspectives. Un cadre de cause à effet pour l'analyse de la pauvreté est proposé ainsi que l'introduction de la notion de 'enclavité' au sein d'une famille en pleine discussion sur la pauvreté. Ce sont là deux contributions majeures du présent document. La recherche propose qu'en raison de la pauvreté qui s’intensifie, les gens se créent des enclaves de protection autour des relations mari/femme comme nouvelle forme de survie/collectivité dans un contexte où les démunis souffrent du manque de biens, de la morale, mais aussi souffrent des réseaux qui s’effritent pour cause de pauvreté. Les résultats de l'étude montrent que, comme énoncé autre part, la pauvreté a plusieurs facettes. Ce qui entraîne une certaine confluence de conceptions.

* University of KwaZulu Natal, School of Development Studies, Howard College Campus. Durban 4041, South Africa. E-mail: simbaomtapuri@yahoo.com. 


\section{Introduction}

Poverty research needs to address the rich-poor conceptual schism because of the differences in meaning that different people attach to these conceptions, especially the rich and the poor. The thesis of this paper is that there is a rich-poor schism that needs to be investigated, especially from the perspective of the poor, in order to be able to do justice to the description and analysis of how people experience poverty. This paper is nested in the tradition that resonates with the others who make a subjective link to poverty. It is crucial to understand these conceptions as a basis to find the points of departure for rural development work as advocated by Chambers, principally if it is coming from the people who experience poverty. Yet, these conceptions are rarely used to describe the poor through their own eyes for purposes of understanding their situations and finding entry points for capacitating them to climb out of poverty.

At both the local and global scale, the situation of the poor seems to be worsening. This is despite the innumerable declarations to eradicate poverty, most notably as enshrined in the Millenium Development Goals (MDGs), which range from halving extreme poverty to halting the spread of HIV/AIDS and providing universal primary education, all by the target date of 2015. These form a blueprint agreed to by all countries and leading development institutions of the world. Milanovic (2003:3) dismisses as simplistic the argument that:

The only thing that a country needs to do is to open its borders, reduce tariff rates, attract foreign capital, and in a few generations if not less, the poor will become rich, the illiterate will learn how to read and write, and inequality will vanish as the poor countries catch up with the rich...leading countries and individuals to a state of economic bliss.

Hochschild (2002) and Anderson, Cavanagh and Lee (2000) note that, on a global scale, over the last 30 years the rich countries have grown richer, the poor countries have become - in both absolute and relative terms - poorer. Also, on a local scale, the rich are getting richer while the poor are becoming more desperate and numerous (in Robeyns 2004:1). In order to know how poor people understand and define poverty, the World Bank undertook a global research effort called Consultations with the Poor, which culminated in the publication of Can Anyone Hear Us? Voices from 47 Countries, Voices of the Poor, which was used to inform the 2000/01 World Development Report on poverty (Narayan 2001; Mowafi n.d). Narayan (2001:39) defines the poor as 'the true poverty experts'. 'While poverty is specific to locations, and indeed to social groups, there is a commonality of the human experience of poverty that cuts across countries, from Nigeria to Egypt, from Malawi to Senegal' (Narayan 2001:40). Understanding these descriptions is an 
academic challenge. A sharper understanding of the phenomenon from the poor's point of view is needed, to be able to measure poverty accurately.

Within the context of South Africa, May (1998) contends that the perceptions of the poor themselves are a good way to derive an appropriate conceptualization of poverty.

In the same vein, Kapungwe (2004:505) argues, in the context of Zambia, that, unless people's perceptions and definitions of poverty and how to deal with it are captured and taken into account, any programmes aimed at combating poverty will yield very little, if any, success. Saunders (2004:4) contends that any definition of poverty should embody

community perceptions (emphasis his) of poverty in some way - as reflected in Henderson's reference to community attitudes, or in Townsend's reference to activities, conditions and amenities that are widely approved, or in Mack and Lansley’s reliance on social perceptions'.

Desai (1988) also grappled with the questions of defining the poor and asked:

Do we mean by poverty some absolute state of existence at or below subsistence, visible to the naked eye, or do we mean a state where some members of a community are relatively worse off, or do we mean defining the poor in terms of subjective/ideological/political criteria?

This paper set off to explore firstly, how the poor of Mashonaland West in Zimbabwe define their situation and create a normative framework for causeeffect relationship and, secondly, to contribute to the discourse of defining the poor from the perspective of the poor. If the poor can be defined in whatever terms in their own eyes, it becomes possible to measure or count the poor in those terms. According to Silverman (2000:122) it may also be possible 'to treat the respondents' answers as describing some external reality (e.g. facts, events) or internal experience (e.g. feelings, meanings). Alternatively, it is a way by which people describe their world (Holstein and Gubrium 1995 as cited by Silverman 2000).

This paper seeks to explore the local perceptions of poverty and the role and importance of assets in Mashonaland West Province in Zimbabwe; establish poverty typologies found in this province; and identify conceptions of assets important to people from different socio-economic profiles for use in the development of a poverty index for African economies.

\section{Data and Empirical Methodology}

A mix of in-depth interviews, focus group discussions (FGDs) as well as semi-structured interviews was used in compiling the data.

Four focus group discussions were held as follows: Group One comprised 5 men and 8 women; Group Two comprised 12 men; Group Three consisted 
of 9 women; Group Four was a mixed group of young people aged 18-24 years old comprising 5 males and 5 females. Mixed groups were used to see whether there is agreement or disagreement on poverty-related issues and engage participants in debate over those issues. All FGDs were recorded on tape. To preserve the anonymity of the participants, all names in this paper are fictitious and conjured.

Face-to-face, in-depth and semi-structured interviews that allowed for probing, were held with five gate-keepers and 30 villagers from the villages of Zimucha, Chakavanda and Washayanyika of Mhondoro Communal Area of Chegutu Rural District in Mashonaland West in Zimbabwe. Mhondoro is situated 40 kilometres from Harare, the capital city of Zimbabwe. Villagers in the area practise subsistence farming and their staple food is maize. The data collected is essentially qualitative in nature as it relied primarily on FGDs and interview data.

In order to minimise response bias, the people who participated in the focus group discussions were different from those who participated in the in-depth and semi-structured interviews. During data analysis, patterns were identified on a thematic basis and thus inductive qualitative analysis was done on the verbatim transcripts of the interviews and the focus group discussion notes. The key themes were: Defining a poor person; Defining a rich person, Typologies of the poor, Describing the most essential items; Strategies to exit poverty; Causes of poverty and Coping mechanisms. The data was collected from 1 December 2006 to 31 January 2007. The description and discussion in this paper does not represent Zimbabwe but represents a single case study in a poor rural setting of Zimbabwe. Access and consent were granted by the local authority, the chief, as well as the participants. Response feedback and feed forward between the researcher and participants were used to validate the findings.

\section{Results}

\section{Defining a Poor Person}

In defining a poor person, recurring themes were identified. The sub-themes were: lack of farming implements, lack of livestock, scavenging for food, husband and wife enclavity, poor dwellings, a life of many struggles and other necessities of life.

\section{Lack of Farming Implements}

In the group discussions, participants portrayed the poor in terms of possessions such as ploughs and related agricultural implements, however rudimentary. Since poverty manifests itself in multi-dimensional realities of multiple deprivations, depictions were made of the poor as people who are hamstrung on many fronts. A 30-year-old woman described it that: 'A poor person is someone who has nothing, who is suffering, he cannot plant crops 
because he does not have the necessary draught power, such as cattle, with which to plough the land'. This conceptualization was also reported by others, also concerned with the absence of resources with which to plough.

\section{Lack of Livestock}

Participants also defined poverty as not having livestock. They agreed that lack of livestock is a contributor to deepening poverty. Other participants defined ownership of cattle as 'mandatory' and such ownership would make one's life 'better'. A 38-year-old mother of two explained that a poor person is someone who may not have chickens or goats or anything to keep. This view is supported by Bird and Shepherd (2003:604), who found out that:

Severe poverty was associated with significant lower levels and common ownership of a number of critical productive assets - oxen (key for agricultural field operations), scotch cart (key for market and common property resource access) and even wheel-barrows (for transporting goods, and even people, over long distances by those without scotch carts. Land... was frequently left uncultivated because of deficits in terms of physical (oxen, in particular), financial (cash) or social capital to access labour.

Lack of cattle seemed to be a common problem for most of the participants, which resulted in the poor not being able to plant and harvest any crops from their fields. It can be inferred that cattle do play a central role in the livelihoods of people in this province who eke out a living on subsistence farming, and yet are faced with a multiple of deprivations that seemingly create a vicious circle.

\section{Scavenging for Food}

Scavenging for food was often mentioned in the group discussions. It became clear for the discussions that the state of being poor led to desperation. The poor resorted to desperate ways of eking out a living to the extent that scavenging for food in the neighbourhood and subsisting on donations became a part of life for the poor. This is in spite of the fact that the poor do have a desire to farm, and ordinarily want also to be self-reliant, as was attested to in the discussions and interviews.

\section{Husband and Wife Enclavity}

Women were identified in male-only focus group discussions as important in the community in which they were described as 'anchors' of the household who fulfil different roles as providers of familial harmony, labour and insurer of food security. The excerpt below illustrates this point:

You must have a wife - without a wife there is no household (Majoni, male, 49-year-old, councillor). 
This view is supported by another respondee who echoed the same sentiment that a wife is a partner in the productive process, who can generate income for use by the family and can play a role of advisor and care giver to the family. The importance of a stable household, in which men and women have clear economic roles, was emphasised.

While males-only focus group discussions mentioned that women are important as providers of income and food to the family, women mentioned the need for a man at the household level for headship. It was clear from the discussion that husband and wife became the locus of familial cohesion in times of desperation. For instance, some women expressed their wish for a male to head the household. One female participant prioritised her needs as follows: husband, savings, cattle, scotch cart, cultivator, harrow, wheelbarrow, goats and chicken in that order. A striking feature is the mention of the need of a husband by female participants and the mention of the need for a female companion by male participants, showing some interdependence and the need for joint livelihoods. In this case, lack of a spouse was associated with vulnerability, and even with theft.

In most group discussions and interviews, the articulation of the need for a spouse can be understood as an indication of a context enabling a new form of practice, if not engendering a new form of resilience. It is perhaps in line with Martha Nussbaum's capability of affiliation as understood as freedom to engage in various social interactions (2000). Having a spouse can provide the promise of accumulation of wealth as he/she can contribute to household welfare in whatever way. If conceived in social safety nets terms, it is meant to ward off vulnerability now and into the future. Such a phenomenon can be understood only when put into context, such as people's own values, value systems, strategies for coping and survival and the challenges before them, perhaps as new forms of collective activity - the creation of enclaves. Spouses are taken as valuable human assets and thus it is possible to infer that poverty encompasses collectivity and resilience. In line with this notion, Dreze and Sen (1989:15) define social security as using social means to prevent deprivation and vulnerability.

In articulating capabilities, Dreze and Sen (1989:13) argue for the broadening of attention from command over food to other influences, including command over other commodities with a bearing on nutrition and health. The argument to add wealth is has merit. People need more than just food and other basic commodities. According to White, Leavy and Masters (2003:381) welfare should be understood as reducing ill being, deprivation or disadvantage, taking whichever term one prefers. Streeten (2000:31) advocates an analysis of self-reliance in culture. 


\section{Poor Dwellings}

In FGDs, dwellings were also mentioned as an indicator of a person's status in the community. The housing type for poor people was described as poor, typically makeshift and empty with no chairs to sit on. This is illustrated by the comment made by one of the participants:

A poor person's dwellings can tell the whole story: His house is constructed using mud and metal tins. Both the roof and the hut are not durable and can collapse in a storm (Bindu, female, 32-year-old mother of two).

It was also mentioned in the discussions that some do not even have doors, lack furniture and are virtually empty to the extent that people sit on reed mats. Some poor people were reported to own a single roundavel (round hut) where the whole family sleeps - parents and children. It became clear that here were people whose living conditions do not permit privacy. This has serious social implications, as it impacts negatively on the children who can slump into anti-social and delinquent behaviour.

\section{A Life of Many Struggles}

Reference was made to a life of perpetual struggle for existence by the poor: a struggle to satisfy basics needs, such as bread; a struggle to keep the children at school; a struggle to remain mentally sound. Thus, poverty becomes a source and cause of both physical and mental stress. The binary deprivations of material and psychological ill being, indicative of psychological deprivation are captured in the following excerpt.

A poor person struggles to make a living. He struggles to get bread, which in most cases he cannot afford. He has no children. Even if he had children, he may still fail to send them to school due to lack of money for school fees (Morand, male, 70-year-old, married, father of five children).

\section{Other Necessities of Life}

The poor also complain about not having the means with which to kick-start their lives such as credit and children for assistance in day-to-day chores. This is also related to the absence of the means to step on to a ladder of asset accumulation. Relativist conceptions of poverty also emerge as this 56-yearold woman had this to say:

A poor person has no vantage point to talk about. He does not even have a wheelbarrow, sometimes no children to help him. And because of hunger, his suffering seems endless as he continues to languish in poverty (Nyembesi, female).

Bird and Shepherd (2003) argue that large family size makes sense in conditions of dependence on subsistence, labour-intensive agriculture and the absence 
of effective social safety nets. By implication, children were regarded as a source of help and a safety net. If children were regarded in those terms, this has serious implications on the health of the women, particularly in the face of the HIV/AIDs pandemic and juxtaposed with the need to reproduce society.

In concluding this section, in most FGDs the major issues raised by the poor concerned their fragile asset bases, the quest for food and the struggle to sustain life on a day-to-day basis. Due to these multiple deprivations, poverty becomes self-perpetuating, pervasive and omnipresent. In summary,

For a poor person it is difficult to find food to eat on a day-to-day basis. Once a poor person, such a person usually remains a poor (John, male, 55-year-old).

The notion of remaining stuck in poverty also suggests that time spent in poverty undermines a person's exit out of poverty.

\section{Defining a Rich Person}

In contrast to the depictions of paucity on all fronts, which characterized the poor, the rich are associated with cattle, availability of agricultural implements, decent housing and good furniture.

A rich person has cattle, ploughing implements such as harrows, scotch cart and cultivator. He has his own chickens and good housing with all the household necessities such as sofas and household utensils 'midziyo yose yemumba', a kitchen with at least 3-5 pots and a couple of plates on the wall shelf. In the bedroom he must have a bed and wardrobe (Monica, female, 48year-old, widow).

Conversely, this also suggests that a poor person does not have these assets. According to the participants in FGDs, good culinary practices and cuisine leading to good health, and attractiveness and beauty of their houses, are identifiers of the rich in the province.

We see a rich person by the beauty inside his house. We see by the things which he owns, which are attractive and nice such as clothing and a brick house. He tills his land, has cattle and eats well. He has no problems, so to speak (Jessica, female, 67-year-old, widow).

Absolute ownership of a house, land and agricultural implements denote riches, if not a high standard of living. The poor make a clear distinction between borrowed and self-owned implements. To be considered rich in the eyes of the poor, one must own these assets and not merely having usufruct rights to the assets. A woman explained:

Possession of self-owned assets of production means that a person can avoid borrowing. 
Thus, ownership ensures continuity of production and the attainment of a high livelihood status in the eyes of observers. However, the views expressed here appear to be very modest views of wealth. It may well suggest that, in fact, the people described would be only a little above the poverty line themselves. This is consistent with the findings of May and Norton (1997:107) that the less poor ploughed with tractors, had cattle and owned livestock.

It was also mentioned that a rich person can also be seen from the attire he and his children wear and the lifestyles they lead. According to the participants, attire reflects a standard of living and social status. However, attire alone cannot be used to gauge a person's poverty status, as some people, especially among the rich, are palpably miserly.

\section{Typologies of the Poor}

The overall picture that emerges is encapsulated in the following typology the poor were defined, on one hand as humble, honest but deprived, and on the other hand as 'scavengers', evil, parasitic, criminal, cheats, dirty and suffering as illustrated in this quote:

The poor work hard, but they are dirty, parasites, matsotsi (thieves) and lazy (Munemo, male, 34-year-old).

Their homes were defined in terms of their structural vulnerability. How is it possible to restore the dignity of the poor given such demeaning descriptions? While Woodhouse (2004:18) argues that because poverty is what happens to vulnerable members of society, the focus should shift from the 'lack' experienced by the poor, but rather to action targeting social values and behaviour among the non-poor. It can be argued that action should rather focus on both the social values and behaviour of both the poor and nonpoor; the poor with respect to their ambitions, expectations and hopes, and the latter with respect to their social responsibilities.

In FGDs words such as 'abundance', 'lots of' and 'many' were commonly used to describe what the rich must have. Participants emphasized that the quality of these assets also matters in distinguishing who is rich and who is not. A poor woman commented:

Arich person's kitchen must have utensils in abundance (midziyo yakawanda) such as pots, dishes, teapots, plates which must be of high quality. In the lounge and dining rooms, there must be high quality sofas, dining tables, display cabinets, room dividers, TVs and a solar energy unit (Tracy, female, 38-year-old, two children). 
The above quote provides some idea of wealth. In most focus group discussions, the participants spoke about the need for asset accumulation as a way to self-sustenance, in as much as it is a way to broaden choice and perhaps to ward off vulnerability. They emphasized that one has to have a start somewhere and build upon it to remain productive and be able to overcome the uncertain and unexpected. This suggests some level of awareness of the potential risks in life and the need to manage those risks at the household level.

What resonates in the focus group discussions and in-depth interviews is that there are many uses of livestock. Participants highlighted that the more livestock and implements one had, in terms of numbers that are of high quality, the better. This attests to the fact that rich people were able to 'strategise' by leveraging their resources to earn more resources. For instance, it was reported in the discussions that they might have between 10-12 cattle deployed differently: some are used as draught power while others are used to collect water from the well/borehole using water bowsers. They have goats, sheep, chickens, turkeys, and even rabbits for meat (personal consumption) and sale. Their granaries are usually fully stocked with food: 'lots of food'. The availability of these resources means that the rich are able to focus solely on farming their fields.

In interviews, participants claimed that rich people can build boreholes and toilets, which poor people cannot do. Even enclosures for their livestock must be well built, such as the cattle pens, pigsties and chicken runs. According to the participants, these are the things that separate the rich from the poor. Rich people were also reported to own shops. Thus, given their vantage point, a 56-year-old woman said:

rich people own the shops from where we buy goods and services and therefore all the money goes back to them. Their children may be working while others may be resident abroad. Life in general goes on smoothly for them - at least from the outside (Nyembesi, female).

A number of people mentioned this caveat, which seems to suggest that there is an awareness that things might not be as they appear. Inherent in that quote is the notion of multiple sources of income. The rich own the shops and receive remittances from their children locally and from the Diaspora. In the discussions, it seemed the rich were getting richer as others felt that those who do not receive assistance via remittances could not compete for goods and services with those who receive them. It became clear that transfers and remittances do destabilize communities if some receive while others do not.

'Adequacy', 'necessities' of life, income generating projects reflect a portrayal of the rich from the point of view of the poor, however subjective. Participants mentioned that rich people enjoy diversified livelihoods 
characterized by 'adequate implements for use at household level and a functioning income-generating project that brings in at least two or three cents every day'.

On one hand, life styles and standards of clothing were cited as indicators of well being associated with the rich. On the other, by inference, a dichotomous scale can be drawn as the testimonies were replete with descriptions of bright/dull; house/hut; joy/sorrow; happiness/suffering; neatness/dirt; beauty/ugliness; mercy/shame; abundance/nothing - to characterize the rich and poor respectively. These adjectives are shown below in the form of a tree diagram (Figure 1).

\section{Figure 1: Tree Diagram of Rich-Poor Schism}

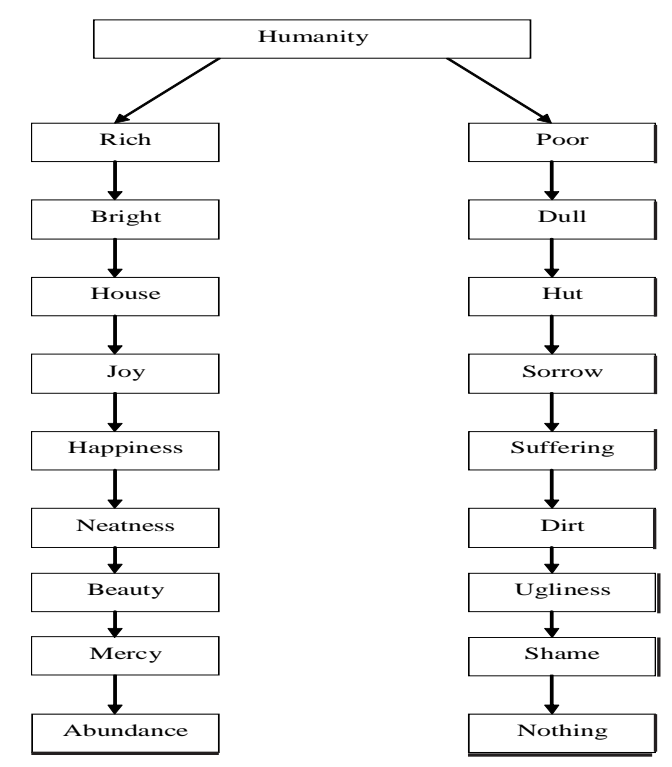

While the typologies show some degree of polarization, these definitions tell us that alternative trajectories are possible: middle ground trajectories with allusions to the hopes and ambitions characterized by equity, equality and egalitarianism. Thus, the binary mapping of the rich and poor that emerges from this paper is one part of understanding poverty and its ramifications. Furthermore, perhaps these typologies can help in finding opportunities for prosperity and wealth for all, as the needs of the poor appear legitimate for 
them to achieve what I call livelihood justice, based on the utilitarian perspective to ethics, which says that a decision or action should achieve greater good for the majority. In addition, typologies guide in transforming mind sets of all stakeholders to transform, reform and craft new, hopefully viable trajectories of the poor that make their lives worth living and to use Narayan's words 'catalyze positive social change’ (2001:47) if necessary.

\section{Describing the Most Essential Items}

In interviews and FGDs, participants were asked to spell out the items they considered essential to exit poverty. As mentioned earlier, cattle came out strongly in all the discussions and across all groups. This is illustrated in the following quote:

You need cattle, a scotch cart, cultivators. Cattle are essential. When the time for ploughing is here, and you do not have cattle, you see others working in their fields as you look and gaze. It is not a good and healthy sight. You see their crops 'mumera' coming up and you do not have such. You feel sorry for yourself. It pains me a lot when you do not have cattle (Monica, 48-year-old, widow).

This excerpt is important in that this person is commenting on what it means to compare one's position as a poor person with that of someone who is not. This brings out the idea of the 'other' - rich.

Participants went as far as equating ownership of cattle with a 'decent and enjoyable life'. Cattle were found to have multiple uses: cattle provide manure, beef, hides and draught power; hence their prominence. Participants argue that it is from ploughing and planting that one gets the food for own consumption and any surplus is then sold on the market to generate and boost household income. Emphasis on cattle suggests animal husbandry is important for the people of this province. Consistently, participants associated capacity to farm with wealth, and conversely incapacity to farm with poverty. Thus, it can be argued that lack of assets such as cattle, as in the case of Mashonaland West, can become a common cause of poverty, without invoking any populism around assets. According to the World Bank (1994:8) in poor rural communities, access to natural resources forms the predominant element of sustaining their day-to-day livelihood and [therefore] access to land for farming and for grazing animals are important.

In FGDs, participants narrated their wish lists which included such items as: projects (chicken and goat rearing); ${ }^{1}$ community gardens; water pumps for irrigation because this area is drought-prone; boreholes to water the gardens; spraying machines for weeding; scotch cart to deliver crops to the market; and electricity. Consultees considered lack of these as impediments to development. The idea of communal ownership of assets was raised in 
focus group discussions. Of importance to the community was a tractor. This is illustrated in the next quote:

We need a tractor. If only we could have a tractor, which would be kept at the councillor's house, that would be excellent. You would pay to have your field ploughed/tilled. It will entirely be up to the individual to work their pieces of land productively after they have been tilled [using the tractor] (Jeremiah, male, 55-year-old).

There is emphasis on the importance of an adequate tractor, although this person appears happy with community-owned equipment. There is also that implied notional movement from community to individual. In a way this says, 'we are members of a community but at the same time we are individuals. We must stand on our own and perhaps be self-reliant'.

With regard to the number of cattle one must have to be considered rich, most FGDs mentioned the range 10 to 18 head of cattle. Respondents highlighted that cattle have a variety of uses in a rural setting. For example, cattle provide milk, beef and skins when slaughtered. Cattle can also be used for ritual purposes and payment of lobola. They are used for ploughing. They can be used as a means of transport, for instance, when transporting grains for milling into mealie meal. Cattle can be used for transporting harvested produce from the garden to the granary. They can be used to carry firewood. Participants also mentioned that a rich person must hold farming inputs such as fertilizers and chemicals, and spare parts for all implements so that production does not stop. The number of assets one owns does matter to the poor.

\section{Strategies to Exit Poverty}

There was a general consensus in the focus group discussion regarding farming as one of the panaceas to poverty. The group observed that some people within their community have managed to buy tractors, while others had bought cars as a result of farming. It was also highlighted in the discussions that some people have been able to educate their children with proceeds from farming. This may well contrast with other areas where people do not see farming as providing an exit from poverty as this could be typical for this area. Such sentiments were captured in the following words:

If only we had enough rains coming as they are doing now, our standard of living would definitely improve, better than in other localities or provinces or even countries. Currently people can't do anything because of the poor rains. If only we had adequate rains, more development would take place in which the improvements in the quality of life of the people would be self-evident. Our people are informed and educated (Munemo, male, 34-year-old). 


\section{Causes of Poverty}

The factors that hinder individuals and families from constructing pathways out of poverty need to be more explicit (Elllis 2003). To that end, this paper attempted to identify some of the factors in Mashonaland West which, according to the participants, included theft, 'the economy' and drought. These factors are examined in this section.

\section{Theft}

One of the major problems plaguing the community was theft: theft from fields, theft from granaries as well as cattle rustling. In-depth interviews with participants revealed that theft in general had become a major cause of poverty affecting many households. Elderly people and women-headed households were the major victims and targets of theft. According to the participants, poverty leads to the commission of criminal acts that also included the theft of chickens, goats and even vegetables from the garden.

With regard to theft, it can be surmised, given the foregoing, that poverty causes the breakdown of ethics; be they cultural or otherwise. As the stocks dwindle and collapse, people look for alternatives including unethical alternatives. Escalating crime affected especially the elderly and female-headed households. Testimonies abounded in the discussions of destitution arising from theft. In view of the increase in theft, consideration should be given to measures that help the poor build their asset base, especially focusing on their needs. Such an argument is premised on the fact that, if everyone has what they need, there is no need to steal from one's neighbour, as illustrated by a 55 -year-old man who commented:

To keep cattle is increasingly becoming difficult because of these criminals who steal cattle at night. You cannot sleep at the cattle kraals at night. People are crying in the community because of theft (Jeremiah).

People expressed a dire need for income generating projects implying that the characterization of the poor as hopeless and defeatist is stereotypical, even if coming from the poor themselves. Rather, it is imperative to understand why poverty-generating circumstances create and recreate themselves among the poor, to the extent that certain pockets of the poor may hold such notions of defeatism. This may hinder development as they sit in the 'comfort' of their poverty. Linked to this is the economy, which was mentioned as not helping the cause of the poor.

\section{The 'Economy'}

The economy ${ }^{2}$ was identified as a cause of poverty. Participants mentioned the ever-increasing prices of basic commodities as causing poverty, because 
the poor could not afford to pay for basic needs. Inflation was mentioned as 'enemy' of the people. This is captured in the quotation:

The economy of the country is not performing well. Inflation is rising everyday and we remain the victims. The rich are becoming richer and the poor poorer (Maduve, female, 38-year-old).

The hyper inflationary environment worked against the poor - measures to restore price stability would be welcome by the poor. A shopkeeper commented:

I change my prices twice or thrice a day. I close my shop when I see people flocking into my shop for a specific item. This signals a big change in prices. They will be wanting to buy from me for re-sell in their shops. We cannot plan in our economy. Food is no longer affordable to many (Johannes, male, 35-year-old).

Ellis (2003) argues that if markets are working well, and trade and exchange are flourishing, then this increases the cash in circulation in rural areas and gives individuals broader opportunities to construct pathways. The trickle up, rather than down, has prevailed as the rich got richer and the poor poorer. Thus the economy takes on a parasitic character when it is supposed to mediate the influences and counterinfluences that work against societal wellbeing. This further challenges neo-liberal orthodoxy or any of its variants. Goulet (1979:59-61) also posits that any strategy entails social costs and sacrificed priorities, and relying on the 'trickle down' alone is not enough without altering the underlying bases of resource uses. Participants also reported that, due to increased unemployment resulting from economic decline, remittances from local sources were dwindling, while those from the Diaspora were increasing.

\section{Drought}

Nature's vicissitude and unexpected climatic changes can have their toll on the livelihoods of people. The issue of drought resonated in the in-depth interviews as well as in the focus group discussions. Drought was mentioned as one of the major causes of hunger and suffering resulting in a shortage of food. The following excerpts crystallize the sentiments:

Drought is one of the major causes of our predicament at the moment. For instance, even if you had two milk cows, drought affects their yield because of lack of grazing pastures. Where would these cows graze? Consequently, where would the milk come from? It affects our yields from our livestock, our crop yields in the gardens as well as yields from our main plots where we grow our staple crops. You cannot make progress. Anything and everything else you do is affected. We cannot do anything without water. For that reason water is precious to us. Drought is stifling and in many ways causes a lot of undue suffering (Munemo, male, 34-year-old). 


\section{Lack of Farming Inputs}

Lack of farming inputs and farming implements have been identified as a cause of poverty. The situation is exacerbated by 'farming failures' emanating from lack of rainwater due to drought and having to pay for hired implements.

In summary, in the focus group discussions, participants cited thefts of assets, illness, extravagant spending, the economy, drought, death in the family, and the state of being poor as causes of poverty. When probed about the effects of poverty, participants highlighted theft, vice and destitution as the significant effects of poverty. Regarding how people in the community coped with poverty, participants mentioned reverse migration from the towns to the rural areas as well as petty theft.

To illustrate this relationship, I develop a model for the analysis of causeeffect-cause of poverty showing how the various proximate determinants are linked to one another (see figure 2 below).

\section{Figure 2: Poverty Cause-Effect Empirical Framework}

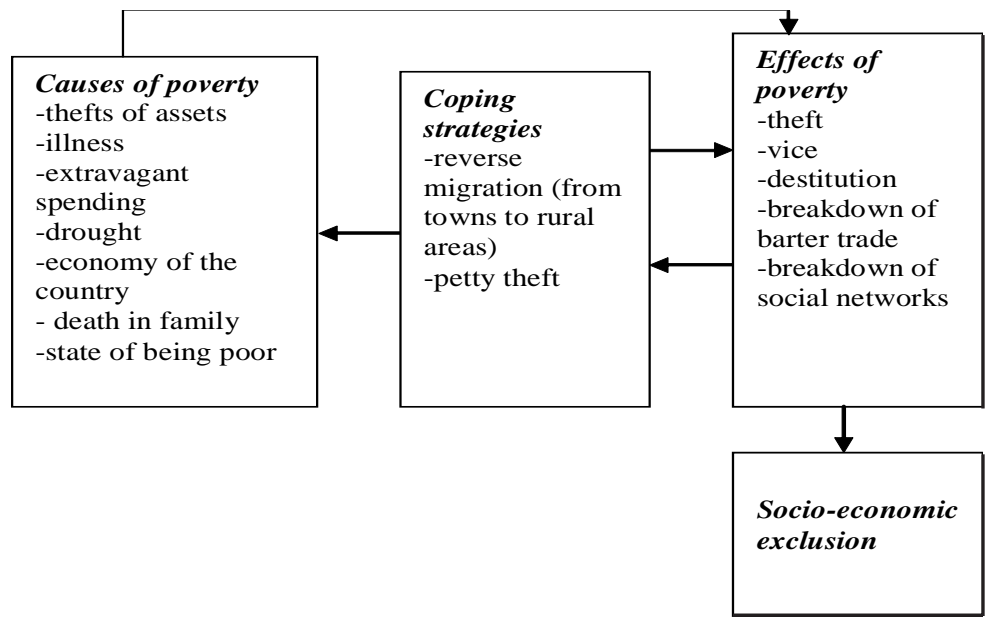

The elaboration of the causes and effects of poverty from the poor's perspective as shown in Figure 2 provides a glimpse of the issues that need to be considered to avoid the social ills associated with being poor and the possibility of crafting options and pathways to exit poverty given such insights.

\section{Coping Mechanisms}

In this research, participants were of the opinion that, in the face of adversity and shocks such as death, drought, hunger and any disaster, NGOs and 
government have a role to play. However, some felt that because of the different foci of NGOs and government, not all who needed assistance got it. The organizations that were mentioned mostly were Christian Care, Salvation Army and parastatal Grain Marketing Board as providing help during drought periods. A participant had this to say:

We do not expect anything from anyone because we do not receive any assistance whatsoever. NGOs have their customary targets such as widows and orphaned children (Farai, male, 45-year-old).

Hopelessness, misery, despondency and helplessness characterized some of the responses from the discussants. From the interview data, it appears that the poor become spiritual in the face of adversity. Poverty emboldens people, as a male adult had this to say:

Generally we exercise patience. As in the Bible, Job had patience and Samson had the strength, thus we derive our patience and strength from the Bible (Chatiza, male, 52-year-old).

It can also be argued that this excerpt may well represent resignation to their existing situation and reflects fatalism rather than becoming bold. Nevertheless, religion is important in shaping perceptions of poverty.

Borrowing was also mentioned in the focus group discussion as a means by which people coped during harsh times. Faced with hunger, people resorted to borrowing: borrowing of cash, implements and grain. At the same time, people were afraid of borrowing cash from moneylenders who were reportedly ruthless when demanding repayments of the loans.

A widely shared sentiment also emerging from the focus group discussions was that barter trade had collapsed because people had no possessions with which to barter. Furthermore, in focus group discussions, the poor testified that the cost of participating in networks was heavy, as this entailed partying with money by way of contributions, such as tithe, which many could no longer afford. Thus, with deepening poverty, barter and informal networks become increasingly fragile and collapse, as testified in FGDs.

\section{Conclusion}

Participants have knowledge of the causes of poverty. The causes of poverty were listed as drought, which decimates livestock and the environment; theft of assets, economy, death in the family and the state of being poor. While drought, theft, death in the family (especially concerning a spouse) appear self-explanatory as their impacts are well documented in literature, the mention of the economy is striking, as it is perceived by the poor as working against them - at least in their eyes. From the evidence, the state of 
being poor invokes trans-generational reproduction of poverty and it became clear that shocks minimize the chances of exiting poverty, especially if their impacts are profound and prolonged such as drought. The findings also show that barter trade collapses in poverty, as the poor do not have items with which to barter. It can be posited that bartering works better where there is room for asset accumulation and a functioning economy where money and other assets are changing hands.

In creating a poverty index, it is imperative to place assets at the core of the index. It became evident from this paper that there is a need to properly manage economy-wide shocks such hyperinflation given their negative impact on the livelihoods of the poor. Of critical importance in that same vein, is the dire need to enhance the capacity and capabilities of the poor to accumulate assets as they open up the possibility of reducing their vulnerability. Some affirmative wealth creating investment aimed at the local level - 'ideally the village' - have merit in providing a partial solution to the alleviation of poverty as Madavo (2001) and Shao (2001) advocate.

Due to the range and limits of the conceptions of poverty, as discussed in this article, it is no wonder that there is not one definition of poverty that has withstood scientific rigour, and at the same time reflects the realities of the poor. It is possible to arrive at a confluence of descriptions precisely that poverty is multifaceted and its causes multi-pronged. It is possible to find solace in the words by Short (1996:1) that there is agreement that all of the definitions capture different pieces of the puzzle while no single measure can yield a complete picture. Hence, the debate rages on.

I agree with the view by May and Norton (2007:115) that qualitative analysis offers unique policy insights that are missed by more conventional methodologies. While some may argue that the poor are not the experts of their situation, in endeavouring they were at least given the opportunity to speak. Thus, the poor have spoken and been heard, and it is safe to aptly conclude with the hopeful words by Achebe et al. (1990:9) that 'the domain of the future is without boundaries'.

\section{Notes}

1. Projects allow for livelihood diversification (see Ellis 1998 as cited in Bird and Shepherd 2003). Bird and Shepherd argue that the diversification of the household economy is an 'acknowledged key to poverty reduction'.

2. This information on the economy of Zimbabwe is taken from the FAO/WFP Crop and Food Supply Assessment Mission to Zimbabwe Report (2007). Agriculture is the mainstay of the Zimbabwe economy in which the majority of the country's population is engaged. The country's economy has been 
declining with the real gross domestic product (GDP) shrinking by about 42 per cent between 1998 and 2006. Unemployment and under-employment are rampant. Poverty has become worse in view of the consecutive depressed harvests and a phenomenal rise in the cost of living relative to the Zimbabwe dollar. Successive crop failures, severely constraining people's coping mechanisms, have compounded people's deprivation. In January 2006, the consumer price inflation was measured at 613 per cent; by April 2007, it had reached a new record of 3,714 per cent. Escalating inflation has consequently been reducing purchasing power of incomes almost daily. The monthly salary of a teacher for example is about Z\$300,000 (about US\$10) when the cost of transport to work alone can be a significant part of that. http://www.fao.org/ docrep/010/10127e/10127e00.htm . 8 June 2008.

\section{Acknowledgements}

I would like to acknowledge the constructive comments on an earlier draft provided by Julian May, Justin Mazengwa, Booker Magure, Horman Chitonge, Maxwell Chanakira, Admire Chirowodza and the two anonymous reviewers. I profited from their insights. Any errors still remaining in this article are mine.

\section{References}

Achebe, C., Goran, H., Achola, P. O. and Magadza, C., 1990, 'Beyond Hunger in Africa’, Heinemann Kenya Limited, Nairobi, Kenya.

Bird, K and Shepherd, A., 2003, 'Livelihoods and Chronic Poverty in Semi-arid Zimbabwe’. World Development, Vol. 31, No. 3, pp. 591-610.

Desai, M and Anup, S., 1988, Oxford Economic Papers, Vol. 40, No. 3. pp. 505-522. Ellis, F., 2003, 'Livelihoods and Poverty reduction in Malawi', World Development, Vol. 31, No. 9, pp. 1495-1510.

Goulet, D., 1979, 'Strategies for Meeting Human Basic Needs'. in M. E. Jegen and C. K. Wilber, eds., Growth with Equity, Paulist Press, New York.

Kapungwe, A., 2004, 'Poverty in Zambia: Levels, patterns and trends', Development Southern Africa, Vol. 21, No.3, pp 483-507, Carfax Publishing, Taylor and Francis Group.

Madavo, C., 2001, 'Serving the Poor in Africa', in B. Deryke, B, R. Calderisi and C. Sigden, eds., Faith in Development, World Bank and Regnum Books International, Oxford, U.K. pp. 51-56.

May, J, and Andy, N., 1997, 'A Difficult Life: The Perceptions and Experience of Poverty in South Africa', Social Indicators Research, 41:95-118, Kluwer Academic Publishers, Netherlands.

May, J., ed., 1998, 'Poverty and Inequality in South Africa’. Report prepared for the Office of the Executive Deputy President and the Inter-ministerial Committee for Poverty and Inequality, Durban: Praxis. 
Mowafi, M. (n.d), The meaning and Measurement of Poverty: A Look into the Global Debate available at http://www.google.co.za/search?hl=en\&q= mona+mowafi\&meta.10 March, 2007.

Milanovic, B., 2003, 'The Two Faces of Globalisation: Against Globalisation as We Know It', World Development, Vol. 31, No. 4, pp. 667-683.

Narayan, D., 2001, ‘Voices of the Poor’, in B. Deryke, R. Calderisi and C. Sigden, eds., Faith in Development, World Bank and Regnum Books International, Oxford, U.K. pp. 39-48.

Nussbaum, M., 2000, ‘Women and Human Development’, Cambridge: Cambridge University Press.

Robeyns, I., 2004, ‘Assessing global poverty and Inequality: Income, resources and capabilities', available at http://ingridrobeyns.nl?Downloads/metaphil.pdf accessed 24 Oct, 2004.

Saunders, P., 2004, 'Towards a Credible Poverty Framework: From Income [poverty to Deprivation’. Social Policy Research Centre, Discussion paper No. 131.

Shao, J., 2001, 'Alleviating poverty in Africa', in B. Deryke, R. Calderisi and C. Sigden eds., Faith in Development, World Bank and Regnum Books International, Oxford, U.K. pp. 19-30.

Silverman, D., 2000, ‘Doing Qualitative Research, A Practical Handbook’, London: Sage Publications.

Streeten, P., 2000, Journal of Human Development, Vol. 1, No. 1, Carfax Publishing, Taylor and Francis Group, pp. 25-48.

White, H.; Jennifer, L; and Andrew, M., 2003, 'Comparative Perspectives on Child Poverty: Review of poverty measures’, Journal of Human Development, Vol. 4, No. 3, Carfax Publishing, Taylor Francis Group, pp. 379-395.

Woodhouse, P., 2004, 'Local identities of poverty: poverty narratives in decentralized government and the role of poverty research in Uganda', available at http://www.gprg.org/pubs/workingpapers/pdfs/gprg-wps-013.pdf . 9 March 2007.

World Bank, 1994, Zambia Poverty Assessment, Volume V: Participatory Poverty Assessment, Africa Regional Office, Report No. 12985-ZA. 